\title{
PERLINDUNGAN HUKUM BAGI TENAGA KERJA ASING TERHADAP PELANGGARAN PERJANJIAN KERJA WAKTU TERTENTU (STUDI KASUS PUTUSAN PENGADILAN HUBUNGAN INDUSTRIAL NOMOR: 274/PDT.SUS-PHI/2015.PN.JKT.PST JO PUTUSAN MAHKAMAH AGUNG NOMOR: 697 K/PDT.SUS-PHI/2016)
}

\author{
Cecilia Puspa Halim \\ (Mahasiswa Program S1 Fakultas Hukum Universitas Tarumanagara) \\ (E-mail: cecilialim.cl@gmail.com)
}

Andari Yurikosari

(Corresponding Author)

(Dosen Hukum Ketenagakerjaan Fakultas Hukum Universitas Tarumanagara, Meraih Sarjana Hukum dari Universitas Indonesia Magister Hukum dari Fakultas Hukum Universitas Indonesia Doktor Hukum dari Fakultas Hukum Universitas Indonesia)

(E-mail: andari.yurikosari@gmail.com)

\begin{abstract}
Law Number 13 of 2013 on Manpower has clearly regulate about work relationship between a foreign labor and Employers of Foreign Labor is only for fixed time employment relations which is based on a Fixed Term of Labor Contract. Article 57 of the Manpower Law stated that a Fixed Term of Labor Contract must be made in writing and must be written in the Indonesian language with Latin alphabets, if not, the agreement shall be reg arde d as a Working Agreement Uncertain Time. A Fixed Term of Labor Contract shall be made based on specified time stated in the work agreement. The author was purposed to find out about how violation of Fixed Term of Labor Contract for Foreign Labor according to Manpower Law, case example: verdict of settlement of industrial relation court number 274/Pdt.Sus-PHI/2015.PN.JKT.PST Juncto Verdict of supreme court number 697K/Pdt.SusPHI/2016 and about legal protection of Foreign Labor who do not have the Fixed Term of Labor Contract in accordance with the Law Number 13 of 2003 on Manpower. The author research this problem using nomative researching method supported by interview data of experts. The author analysis that violations of Fixed Term of Labor Contract done by PT Wira Pamungkas Pariwara againts Lau Chak Loong are the Fixed Term of Labor Contract was made and sign in foreign language and didn't contain fixed time agreement caused ambiguous foreign labor status to claim his rights.
\end{abstract}

Keywords: Fixed Term of Labor Contract, Foreign Labor, Law Protection. 


\section{Pendahuluan}

\section{A. Latar Belakang}

Problematika ketenagakerjaan/perburuhan sepanjang masa tidak pernah selesai dari masalah perlindungan, pengupahan, kesejahteraan, perselisihan hubungan industrial, pembinaan, dan pengawasan ketenagakerjaan. Hal ini diakibatkan kelemahan Pemerintah secara sistemik dalam mengimplementasikan undang-undang ketenagakerjaan, bahkan cenderung ada penyimpangan, hal lain masalah koordinasi dan kinerja antarlembaga Pemerintah belum optimal dan masih sangat memprihatinkan. ${ }^{1)}$

Pembangunan nasional yang penuh tantangan dan persaingan global akan banyak diwarnai oleh pentingnya kualitas Sumber Daya Manusia (yang selanjutnya disebut SDM) yang menguasai Ilmu Pengetahuan dan Teknologi (yang selanjutnya disebut IPTEK). SDM berkualitas sangat menentukan hari depan bangsa. Pengembangan SDM muncul dan merupakan kebutuhan mendesak di semua sektor dan sub sektor pembangunan.

Sumber Daya Manusia dianggap sebagai faktor penentu dan merupakan aset yang paling berharga dalam upaya pembangunan yang telah, sedang dan akan dilaksanakan. Sebagai sumber daya pembangunan serta pelaku pembangunan, SDM harus memiliki etos kerja yang produktif, keterampilan, kreativitas, disiplin dan profesionalisme, serta mampu memanfaatkan, mengembangkan dan menguasai IPTEK.

Untuk memajukan dan meningkatkan pembangunan serta pertumbuhan ekonomi, menyebabkan Pemerintah membuka kesempatan bagi negara lain untuk menanamkan modalnya di negara Indonesia. Hal ini memungkinkan dipergunakannya Tenaga Kerja Asing (yang selanjutnya disebut TKA) di perusahaan swasta. Keberadaan TKA di pasar kerja Indonesia dewasa ini telah menjadi fenomena yang lumrah. Latar belakang keberadaan TKA di Indonesia

\footnotetext{
1) Adrian Sutedi, Hukum Perburuhan, Cetakan ke-1, (Jakarta: Sinar Grafika, 2009), 141.
} 
pun telah mengalami perubahan sesuai dengan perkembangan zaman. Dahulu keberadaan TKA di Indonesia untuk keperluan pembangunan nasional, dewasa ini keberadaan TKA merupakan bagian dari era pasar bebas atau era globalisasi.

Untuk mempekerjakan TKA, pemberi kerja TKA harus memiliki Rencana Penggunaan Tenaga Kerja Asing (yang selanjutnya disebut RPTKA) yang disahkan oleh Menteri atau pejabat yang ditunjuk. ${ }^{2)}$ Rencana Penggunaan Tenaga Kerja Asing paling sedikit memuat: ${ }^{3)}$

1. Alasan penggunaan TKA;

2. Jabatan dan/atau kedudukan TKA dalam struktur organisasi perusahaan yang bersangkutan;

3. Jangka waktu penggunaan TKA; dan

4. Penunjukan tenaga kerja Indonesia sebagai pendamping TKA yang dipekerjakan.

Peraturan Menteri Ketenagakerjaan Republik Indonesia Nomor 35 Tahun 2015 Tentang Perubahan Atas Peraturan Menteri Ketenagakerjaan Nomor 16 Tahun 2015 Tentang Tata Cara Penggunaan Tenaga Kerja Asing mewajibkan setiap pemberi kerja TKA memiliki Izin Mempekerjakan Tenaga Kerja Asing (yang selanjutnya disebut IMTA) yang diterbitkan oleh Direktur. ${ }^{4)}$ Jangka waktu berlakunya IMTA diberikan paling lama 1 (satu) tahun dan dapat diperpanjang sesuai dengan Keputusan Menteri tentang jabatan-jabatan yang dapat diduduki oleh TKA atau RPTKA. ${ }^{5)}$ Izin Mempekerjakan Tenaga Kerja Asing menjadi dasar untuk pengajuan: ${ }^{6}$

2) Indonesia, Undang-Undang Nomor 13 Tahun 2003 Tentang Ketenagakerjaan, Pasal 43 Ayat (1).

3) Indonesia, Peraturan Presiden Republik Indonesia Nomor 20 Tahun 2018 tentang Penggunaan Tenaga Kerja Asing, Pasal 7.

4) Indonesia, Peraturan Menteri Ketenagakerjaan Republik Indonesia Nomor 35 Tahun 2015 Tentang Perubahan Atas Peraturan Menteri Ketenagakerjaan Nomor 16 Tahun 2015 Tentang Tata Cara Penggunaan Tenaga Kerja Asing, Pasal 37 Ayat (1).

5) Ibid., Pasal 39 Ayat (1).

${ }^{6)}$ Ibid., Pasal 39 Ayat (3). 
1. Penerbitan persetujuan visa;

2. Pemberian dan perpanjangan Izin Tinggal Terbatas (ITAS);

3. Alih status izin tinggal kunjungan (ITK) menjadi ITAS;

4. Alih status ITAS menjadi Izin Tinggal Tetap (ITAP); dan

5. Perpanjangan ITAP.

Tenaga Kerja Asing dapat dipekerjakan di Indonesia hanya dalam hubungan kerja untuk jabatan tertentu dan waktu tertentu. ${ }^{7)}$ Hubungan kerja merupakan sesuatu yang abstrak. Ia merupakan hubungan hukum antara seorang majikan dengan seorang buruh. Dalam melakukan hubungan kerja haruslah dilakukan sesuai dengan waktu yang telah ditentukan dalam perjanjian kerja atau peraturan perundang-undangan. Pelaksanaan pekerjaan tersebut juga harus sesuai dengan isi dalam perjanjian kerja dan juga tidak boleh bertentangan dengan ketentuan peraturan perundang-undangan, kebiasaan setempat, dan ketertiban umum. ${ }^{8)}$ Hubungan kerja hanya lahir karena perjanjian kerja. Perjanjian kerja melahirkan perikatan. Perikatan yang lahir karena perjanjian kerja inilah yang merupakan hubungan kerja. ${ }^{9)}$

Perjanjian kerja diatur dalam Bab IX Undang-Undang Nomor 13 Tahun 2003 tentang Ketenagakerjaan. Pasal 1 Angka 14 Undang-Undang Nomor 13 Tahun 2003 tentang Ketenagakerjaan menyatakan bahwa perjanjian kerja adalah perjanjian antara pekerja/buruh dengan pengusaha atau pemberi kerja yang memuat syarat-syarat kerja, hak, dan kewajiban para pihak. Subyek hukum dalam perjanjian kerja pada dasarnya adalah pengusaha/pemberi kerja dengan pekerja/buruh. ${ }^{10)}$ Obyek dalam perjanjian kerja adalah tenaga yang

7) Ibid., Pasal 42 Ayat (4).

8) Djumadi, Hukum Perburuhan Perjanjian Kerja, Cetakan ke-5, (Jakarta: Raja Grafindo Persada, 2008), 40.

9) Abdul Rachmad Budiono, Hukum Perburuhan Di Indonesia, Cetakan ke-3, (Jakarta: Raja Grafindo Persada, 1999), 25.

10) Asri Wijayanti, Hukum Ketenagakerjaan Pasca Reformasi, Cetakan ke-1, (Jakarta: Sinar Grafika, 2009), 40. 
melekat pada diri pekerja. Atas dasar tenaga telah dikeluarkan oleh pekerja/buruh maka ia akan mendapatkan upah. ${ }^{11)}$

Hal ini menunjukan bahwa hubungan kerja antara pengusaha dan TKA didasarkan atas Perjanjian Kerja Waktu Tertentu (yang selanjutnya disebut PKWT). Perjanjian Kerja Waktu Tertentu adalah perjanjian kerja antara pekerja/buruh dengan pengusaha untuk mengadakan hubungan kerja dalam waktu tertentu atau untuk pekerjaan tertentu. ${ }^{12)}$ Perjanjian Kerja Waktu Tertentu harus memenuhi syarat-syarat sebagai berikut: ${ }^{13)}$

1. Harus mempunyai jangka waktu tertentu; atau

2. Adanya suatu pekerjaan yang selesai dalam waktu tertentu; dan

3. Tidak mempunyai syarat dan masa percobaan.

Perjanjian Kerja Waktu Tertentu tidak dapat mensyaratkan adanya masa percobaan kerja, dalam hal disyaratkan masa percobaan kerja falam perjanjian kerja, masa percobaan kerja yang disyaratkan batal demi hukum. Pasal 59 Ayat (1) Undang-Undang Nomor 13 Tahun 2003 Tentang Ketenagakerjaan menyatakan PKWT hanya dapat dibuat untuk pekerjaan tertentu yang menurut jenis dan sifat atau kegiatan pekerjaannya akan selesai dalam waktu tertentu, yaitu:

a. Pekerjaan yang sekali selesai atau yang sementara sifatnya;

b. Pekerjaan yang diperkirakan penyelesaiannya dalam waktu yang tidak terlalu lama dan paling lama 3 (tiga) tahun;

c. Pekerjaan yang bersifat musiman; atau

d. Pekerjaan yang berhubungan dengan produk baru, kegiatan baru, atau produk tambahan yang masih dalam percobaan atau penjajakan.

11) Ibid., 41. 2008), 11 .

12) F.X. Djumialdji, Perjanjian Kerja Edisi Revisi, Cetakan ke-3, (Jakarta: Sinar Grafika,

13) Aloysius Uwiyono et al., Asas-asas Hukum Perburuhan, Cetakan ke-2, (Jakarta: Raja Grafindo Persada, 2014), 64. 
Undang-Undang Nomor 13 Tahun 2003 tentang Ketenagakerjaan mengatur bahwa TKA dilarang menduduki jabatan yang mengurusi personalia dan/atau jabatan-jabatan tertentu. ${ }^{14)}$ Jabatan-jabatan yang dilarang diduduki oleh TKA diatur lebih lanjut dalam Keputusan Menteri Tenaga Kerja dan Transmigrasi Nomor 40 Tahun 2012 Tentang Jabatan-Jabatan Tertentu Yang Dilarang Diduduki Tenaga Kerja Asing.

Terdapat perbedaan antara perjanjian pada umumnya dengan perjanjian kerja. Pada pengertian perjanjian pada umumnya, kedudukan antara para pihak yang mengadakan perjanjian adalah sama dan seimbang, sedangkan pada pengertian perjanjian kerja, para pihak yang mengadakan perjanjian tidak dalam kedudukan yang sama dan seimbang karena pihak yang satu yaitu pekerja mengikatkan diri dan bekerja di bawah perintah orang lain, yaitu pengusaha. ${ }^{15)}$

Pemerintah baru saja mengeluarkan Peraturan Presiden Nomor 20 Tahun 2018 tentang Penggunaan Tenaga Kerja Asing. Hal ini dilakukan Pemerintah dengan pertimbangan untuk mendukung perekonomian nasional dan perluasan kesempatan kerja melalui peningkatan investasi, pemerintah memandang perlu pengaturan kembali perizinan penggunaan TKA. ${ }^{16)}$ Perpres ini diharapkan bisa mempermudah TKA masuk ke Indonesia yang berujung pada peningkatan investasi dan perbaikan ekonomi nasional. ${ }^{17)}$

${ }^{14)}$ Indonesia, Op. Cit., Pasal 46 Ayat (1).

15) Djumadi, Op. Cit., 13.

16) Humas, "Inilah Perpres Nomor 20 Tahun 2018 tentang Penggunaan Tenaga kerja Asing", http://setkab.go.id/inilah-perpres-nomor-20-tahun-2018-tentang-penggunaan-tenaga-kerja-asing, diakses tanggal 29 Mei 2018.

${ }^{17)}$ Woro Seto, "Perpres Nomor 20 Tahun 2018, Fadli Zon: Isu TKA Bukan Sengaja Digoreng atau Dibesar-besarkan", http://wow.tribunnews.com/2018/05/02/perpres-nomor-20-tahun-2018-fadlizon-isu-tka-bukan-sengaja-digoreng-atau-dibesar-

besarkan?page=all\&_ga=2.179204390.387434045.1527577159-1770462426.1514646508, diakses tanggal 29 Mei 2018. 
Pada praktiknya keberadaan PKWT bagi TKA tersebut sering timbul permasalahan. Salah satu permasalahannya adalah banyak PKWT yang dibuat oleh pengusaha dengan TKA tidak dibuat dalam bahasa Indonesia melainkan dalam bahasa Inggris atau bahasa asing lainnya, sehingga menimbulkan pertanyaan bagaimana keabsahan dari PKWT tersebut. Pasal 57 Ayat (1) dan Ayat (2) Undang-Undang Nomor 13 Tahun 2003 tentang Ketenagakerjaan secara tegas menyatakan bahwa PKWT harus dibuat secara tertulis serta harus dibuat dalam bahasa Indonesia dan huruf latin atau setidak-tidaknya dalam bilingual (mengandung dua bahasa, yaitu Bahasa Indonesia dan bahasa asing). Apabila PKWT tidak dibuat secara tertulis serta tidak menggunakan bahasa Indonesia dan huruf latin, PKWT dinyatakan sebagai Perjanjian Kerja Waktu Tidak Tertentu (yang selanjutnya disebut PKWTT). Permasalahan lainnya ialah mengenai jangka waktu penggunaan TKA tersebut. Pasal 42 Ayat (4) Undang-Undang Nomor 13 Tahun 2003 tentang Ketenagakerjaan menyatakan bahwa TKA dapat dipekerjakan di Indonesia hanya dalam hubungan kerja untuk jabatan tertentu dan waktu tertentu. Pasal 59 Ayat (4) dan Ayat (6) Undang-Undang Nomor 13 Tahun 2003 tentang Ketenagakerjaan menyatakan pula bahwa PKWT dapat diadakan paling lama 2 (dua) tahun dan dapat diperpanjang 1 (satu) kali untuk jangka waktu paling lama 1 (satu) tahun dan pembaruan PKWT hanya boleh dilakukan 1 (satu) kali dan paling lama 2 (dua) tahun. Namun pada kenyataannya masih banyak perjanjian kerja yang dibuat antara pengusaha dan TKA tidak mengatur jangka waktu maupun melebihi jangka waktu yang ditentukan oleh Undang-Undang Nomor 13 Tahun 2003 tentang Ketenagakerjaan. Padahal keberadaan TKA di Indonesia hanyalah untuk keperluan ahli teknologi dan ahli keahlian selama tenaga kerja dalam negeri belum memiliki kemampuan untuk mengisi jabatan tersebut sehingga jangka waktu penggunaan TKA dibatasi.

Ketentuan Pasal 42 Ayat (4) Undang-Undang Nomor 13 Tahun 2003 tentang Ketenagakerjaan mengenai TKA yang hanya dapat dipekerjakan 
untuk waktu tertentu bertentangan dengan ketentuan Pasal 57 Ayat (1) dan Ayat (2) Undang-Undang Nomor 13 Tahun 2003 tentang Ketenagakerjaan yang menyatakan bahwa PKWT harus dibuat secara tertulis serta harus menggunakan bahasa Indonesia dan huruf latin, apabila tidak dibuat secara tertulis serta menggunakan bahasa Indonesia dan huruf latin, secara hukum dinyatakan menjadi PKWTT. Dampak dari hal tersebut terlihat ketika terjadi perselisihan hubungan industrial terkait Pemutusan Hubungan Kerja (yang selanjutnya disebut PHK) antara pengusaha dan TKA tersebut.

Hal tersebut dapat dilihat dari putusan Pengadilan Hubungan Industrial Nomor: 274/Pdt.Sus-PHI/2015.PN.JKT.PST dan putusan Mahkamah Agung Nomor: 697 K/Pdt.Sus-PHI/2016 yang merupakan putusan dalam perkara perselisihan hubungan industrial terkait PHK antara Lau Chak Loong, warga negara Malaysia dan PT Wira Pamungkas Pariwara. Pada perkara tersebut, Lau Chak Loong telah bekerja di PT Wira Pamungkas Pariwara selama lebih dari 4 (empat) tahun berdasarkan Employment Agreement tanggal 30 Juni 2011. Employment Agreement tersebut tidak mengatur mengenai jangka waktu perjanjian kerja dan perjanjian kerja tersebut tidak pernah dilakukan perpanjangan, perubahan, pembaharuan, atau amandemen. Employment Agreement tersebut dibuat dan ditandatangani dalam bahasa Inggris tanpa adanya terjemahan bahasa Indonesia sehingga perselisihan timbul ketika PT Wira Pamungkas Pariwara melakukan pemutusan hubungan kerja secara sepihak kepada Lau Chak Loong.

Berdasarkan uraian latar belakang tersebut, maka Penulis tertarik untuk melakukan kajian lebih lanjut secara komperehensif dan menuangkannya dengan judul "Perlindungan Hukum Bagi Tenaga Kerja Asing Terhadap Pelanggaran Perjanjian Kerja Waktu Tertentu (Studi Kasus Putusan Pengadilan Hubungan Industrial Nomor: 274/Pdt.Sus-PHI/2015.PN.JKT.PST Jo Putusan Mahkamah Agung Nomor: 697 K/Pdt.Sus-PHI/2016)”. 


\section{B. Perumusan Masalah}

Berdasarkan uraian latar belakang di atas, maka pokok permasalahan yang akan dibahas adalah:

1. Bagaimana pelanggaran Perjanjian Kerja Waktu Tertentu bagi Tenaga Kerja Asing berdasarkan Undang-Undang Nomor 13 Tahun 2003 tentang Ketenagakerjaan pada kasus Putusan Pengadilan Hubungan Industrial Nomor: 274/Pdt.Sus-PHI/2015.PN.JKT.PST Juncto Putusan Mahkamah Agung Nomor: 697 K/Pdt.Sus-PHI/2016?

2. Bagaimana perlindungan hukum terhadap Tenaga Kerja Asing yang tidak memiliki Perjanjian Kerja Waktu Tertentu yang sesuai dengan UndangUndang Nomor 13 Tahun Nomor 2003 tentang Ketenagakerjaan?

\section{Pembahasan}

A. Pelanggaran Perjanjian Kerja Waktu Tertentu Bagi Tenaga Kerja Asing Berdasarkan Undang-Undang Nomor 13 Tahun 2003 Tentang Ketenagakerjaan Pada Kasus Putusan Pengadilan Hubungan Industrial Nomor: 274/Pdt.Sus-PHI/2015.PN.JKT.PST Jo Putusan Mahkamah Agung Nomor: 697 K/Pdt.Sus-PHI/2016

Pasal 57 Ayat (1) dan Ayat (2) Undang-Undang Nomor 13 Tahun 2003 tentang Ketenagakerjaan mengatur bahwa PKWT harus dibuat secara tertulis serta harus menggunakan bahasa Indonesia dan huruf latin. Apabila PKWT tidak dibuat secara tertulis serta tidak menggunakan bahasa Indonesia dan huruf latin, maka PKWT tersebut demi hukum dinyatakan sebagai PKWTT. Masalah pelanggaran perjanjian kerja antara TKA dan PT Wira Pamungkas Pariwara, yang Pertama adalah PKWT antara Lau Chak Loong dan PT Wira Pamungkas Pariwara dibuat dan ditandatangani dalam bahasa Inggris tanpa adanya terjemahan dalam bahasa Indonesia yang terbukti dalam Putusan Pengadilan Hubungan Industrial Nomor: 274/Pdt.Sus-PHI/2015.PN.JKT.PST bukti P-1, sedangkan Pasal 57 Ayat (1) Undang-Undang Nomor 13 Tahun 
2003 tentang Ketenagakerjaan mengatur bahwa PKWT harus dibuat secara tertulis serta dalam bahasa Indonesia dan huruf latin, apabila menggunakan bahasa asing, PKWT tersebut harus dibuat dalam 2 (dua) bahasa, yaitu dalam bahasa asing dan bahasa Indonesia. Berdasarkan Pasal 57 Ayat (2) Undang Nomor 13 Tahun 2003 tentang Ketenagakerjaan, PKWT yang tidak dibuat secara tertulis serta tidak menggunakan bahasa Indonesia dan huruf latin dinyatakan sebagai PKWTT, maka seharusnya PKWT yang dibuat antara Lau Chak Loong dan PT Wira Pamungkas Pariwara demi hukum berubah menjadi PKWTT sesuai dengan yang diatur dalam Pasal 57 Ayat (2) Undang-Undang Nomor 13 Tahun 2003 tentang Ketenagakerjaan. Pada pertimbangan hukumnya, Majelis Hakim Agung dalam perkara tersebut tidak hanya mempertimbangkan adanya alat bukti PKWT yang dibuat dalam bahasa Inggris saja namun Majelis Hakim Agung juga mempertimbangkan alat bukti RPTKA dan KITAS sebagai salah satu persyaratan izin kerja yang harus dimiliki oleh TKA sebagai alat bukti adanya hubungan kerja waktu tertentu antara PT Wira Pamungkas Pariwara dan Lau Chak Loong. Kartu Ijin Tinggal Terbatas tersebut memiliki jangka waktu yang terbatas sampai dengan tanggal 27 Juli 2015. Keberadaan KITAS tersebut secara tegas menunjukkan bahwa hubungan kerja antara PT Pamungkas Pariwara dan Lau Chak Loong dibuat dalam hubungan kerja waktu tertentu. Meskipun PKWT antara PT Pamungkas Pariwara dan Lau Chak Loong dibuat dalam bahasa Inggris yang bertentangan dengan ketentuan Pasal 57 Ayat (1) Undang-Undang Nomor 13 Tahun 2003 tentang Ketengakerjaan namun tidak serta merta menjadikan PKWT tersebut menjadi PKWTT karena keberadaan alat-alat bukti surat lainnya yaitu KITAS yang mempertegas bahwa hubungan kerja antara PT Pamungkas Pariwara dan Lau Chak Loong merupakan hubungan kerja waktu tertentu.

Pasal 59 Ayat (4) Undang-Undang Nomor 13 Tahun 2003 tentang Ketenagakerjaan mengatur bahwa PKWT yang didasarkan atas jangka waktu tertentu dapat diadakan untuk paling lama 2 (dua) tahun dan hanya boleh 
diperpanjang 1 (satu) kali untuk jangka waktu paling lama 1 (satu) tahun. Pasal 59 Ayat (6) Undang-Undang Nomor 13 Tahun 2003 tentang Ketenagakerjaan mengatur bahwa PKWT dapat dilakukan pembaruan setelah melebihi masa tenggang waktu 30 (tiga puluh) hari berakhirnya PKWT yang lama dengan jangka waktu diadakan untuk 1 (satu) kali dan paling lama 2 (dua) tahun. Undang-Undang Nomor 13 Tahun 2003 tentang Ketenagakerjaan secara tegas mengatur bahwa penggunaan TKA di Indonesia dibatasi. Pembatasan tersebut untuk jabatan tertentu dan waktu tertentu. Keberadaan TKA di Indonesia hanyalah untuk keperluan ahli teknologi dan ahli keahlian selama tenaga kerja dalam negeri belum memiliki kemampuan untuk mengisi jabatan tersebut sehingga jangka waktu penggunaan TKA dibatasi. Masalah pelanggaran PKWT antara Lau Chak Loong dan PT Pamungkas Pariwara, yang Kedua adalah Lau Chak Loong telah bekerja pada PT Wira Pamungkas Pariwara selama 4 (empat) tahun sejak tahun 2011 sampai dengan tahun 2015 berdasarkan Employment Agreement tertanggal 30 Juni 2011. Lau Chak Loong mulai bekerja sejak tanggal 1 Juli 2011 sampai dengan jangka waktu yang tidak ditentukan dalam perjanjian kerja. Di mana dalam perjanjian kerja tersebut hanya mengatur ketentuan mengenai pengakhiran hubungan kerja sebagai berikut: "14.1 You or we may terminate this Agreement by informing each other in writing at least three (3) months in advance or payment of an eguivalent amount of the Salary in lieu of any notice period". Yang terjemahan bebasnya adalah sebagai berikut: "Anda atau kami berhak mengakhiri perjanjian ini dengan memberitahukan satu sama lain secara tertulis paling lambat 3 (tiga) bulan sebelumnya atau pembayaran dalam sejumlah gaji sebagai pengganti masa pemberitahuan". Employment Agreement tersebut tidak pernah dilakukan perpanjangan, perubahan, maupun pembaharuan.

Pada tanggal 31 Maret 2015, Chief Excecutive Officer Young \& Rubicam Asia Tenggara mengeluarkan Notice of Termination yang intinya bermaksud 
untuk mengakhiri hubungan kerja antara Lau Chak Loong dengan PT Wira Pamungkas Pariwara. Lau Chak Loong dengan tegas menolak surat tersebut karena satu-satunya hubungan kerja yang diakui adalah berdasarkan Employment Agreement dengan PT Wira Pamungkas Pariwara. Pada tanggal 6 April 2015, Direktur PT Wira Pamungkas Pariwara mengeluarkan surat yang pada intinya merujuk pada surat dari Chief Excecutive Officer Young \& Rubicam Asia Tenggara sebelumnya terkait dengan pemutusan hubungan kerja terhadap Lau Chak Loong.

Dari segi jangka waktu, Lau Chak Loong telah bekerja di Indonesia selama 4 tahun terhitung sejak tahun 2011 sampai dengan tahun 2015. Berdasarkan Undang-Undang Nomor 13 Tahun 2003 tentang Ketenagakerjaan, maka hubungan kerja antara Lau Chak Loong dan PT Pamungkas Pariwara telah melanggar ketentuan Pasal 59 Ayat (4) UndangUndang Nomor 13 Tahun 2003 tentang Ketenagakerjaan yang menyatakan bahwa PKWT yang didasarkan atas jangka waktu tertentu dapat diadakan untuk paling lama 2 (dua) tahun dan hanya boleh diperpanjang 1 (satu) kali untuk jangka waktu paling lama 1 (satu) tahun, karena Lau Chak Loong telah bekerja dengan jangka waktu lebih dari apa yang diatur oleh undang-undang, yaitu Lau Chak Loong telah bekerja selama 4 (empat) tahun, di mana akibat hukum dari pelanggaran Pasal 59 Ayat (4) Undang-Undang Nomor 13 Tahun 2003 tentang Ketenagakerjaan, yaitu PKWT demi hukum berubah menjadi PKWTT (Pasal 59 Ayat (7) Undang-Undang Nomor 13 Tahun 2003 tentang Ketenagakerjaan). Undang-Undang Nomor 13 Tahun 2003 tentang Ketenagakerjaan secara tegas mengatur bahwa penggunaan TKA di Indonesia dibatasi untuk jabatan tertentu dan waktu tertentu (Pasal 42 Ayat (4) UndangUndang Nomor 13 Tahun 2003 tentang Ketenagakerjaan). Keberadaan TKA di Indonesia hanyalah untuk keperluan ahli teknologi dan ahli keahlian selama tenaga kerja dalam negeri belum memiliki kemampuan untuk mengisi jabatan tersebut agar bisa terjadi proses transfer of expertise atau transfer keahlian, 
teknologi dan pengetahuan dari TKA kepada tenaga kerja dalam negeri sehingga jangka waktu penggunaan TKA harus dibatasi. ${ }^{18)}$ Berdasarkan hasil wawancara dengan Bapak M. Rizki Nasution, ${ }^{19)}$ bahwa TKA tidak tunduk pada Pasal 59 Undang-Undang Nomor 13 Tahun 2003 tentang Ketenagakerjaan yang mengatur mengenai jangka waktu PKWT. Jangka waktu bekerja TKA mengikuti jangka waktu berlakunya IMTA. Untuk IMTA yang jangka waktu berlakunya di bawah 6 (enam) bulan, maka IMTA tersebut tidak dapat diperpanjang. Untuk IMTA yang jangka waktu berlakunya di atas 6 (enam) bulan, dapat diperpanjang dengan diberikan paling lama 1 (satu) tahun. Karena dalam perjanjian kerja tidak mengatur mengenai jangka waktu, maka jangka waktu bekerja TKA mengikuti yang tertera pada KITAS. KITAS TKA tersebut berakhir pada bulan Juli 2015 yang artinya hubungan kerja antara Lau Chak Loong dan PT Wira Pamungkas Pariwara berakhir pada Juli 2015, namun hubungan kerja antara Lau Chak Loong dan PT Wira Pamungkas Pariwara berakhir pada bulan Juni 2015. Artinya perusahaan seharusnya memberikan ganti rugi 1 (satu) bulan kepada TKA karena masih ada tersisa jangka waktu 1 (satu) bulan sebelum KITAS berakhir. Namun dalam Putusan Pengadilan Hubungan Industrial Nomor: 274/Pdt.SusPHI/2015.PN.JKT.PST Jo Putusan Mahkamah Agung Nomor: 697 K/Pdt.SusPHI/2016, hakim tidak memberikan ganti rugi 1 (satu) bulan kepada Lau Chak Loong.

Pasal 56 Ayat (2) Undang-Undang Nomor 13 Tahun 2003 tentang Ketenagakerjaan menyatakan bahwa PKWT didasarkan atas jangka waktu dan selesainya suatu pekerjaan tertentu, di mana Pasal 59 Ayat (4) UndangUndang Nomor 13 Tahun 2003 tentang Ketenagakerjaan mengatur bahwa

${ }^{18)}$ Safri Haliding, "Pengawasan Tenaga Kerja Asing",

http://thinktank.matagaruda.org/read/74/pengawasan-tenaga-kerja-asing, diakses pada tanggal 5 Juni 2018.

${ }^{19)}$ Peneliti, Wawancara, dengan Kasi Pelatihan dan Penempatan Tenaga Kerja Dalam Negeri Kementerian Ketenagakerjaan Republik Indonesia, (Jakarta: Kementerian Ketenagakerjaan Republik Indonesia, 22 Maret 2018). 
PKWT yang didasarkan atas jangka waktu tertentu dapat diadakan untuk paling lama 2 (dua) tahun dan hanya boleh diperpanjang 1 (satu) kali untuk jangka waktu paling lama 1 (satu) tahun. Perjanjian Kerja Waktu Tertentu tentunya harus didasarkan atas jangka waktu tertentu yang termuat dalam perjanjian kerja. Masalah pelanggaran PKWT antara Lau Chak Loong dan PT Wira Pamungkas Pariwara, yang Ketiga adalah perjanjian kerja yang dibuat tidak memuat jangka waktu berlakunya yang terbukti dalam Putusan Pengadilan Hubungan Industrial Nomor: 274/Pdt.Sus-PHI/2015.PN.JKT.PST Jo Putusan Mahkamah Agung Nomor: 697 K/Pdt.Sus-PHI/2016 bukti P-1 dan perjanjian kerja tersebut tidak pernah dilakukan perperpanjangan, perubahan, maupun pemberbaharuan. Perjanjian Kerja Waktu Tertentu seharusnya memuat jangka waktu berlakunya perjanjian kerja karena perjanjian kerja tersebut didasarkan pada jangka waktu tertentu, apabila tidak memuat jangka waktu perjanjian tersebut, perjanjian tersebut dapat dikatakan sebagai PKWTT karena tidak ada waktu tertentu yang menjadi dasar dari perjanjian kerja tersebut. Selain itu juga dengan tidak dicantumkannya jangka waktu berlakunya perjanjian kerja dapat menimbulkan ketidakjelasan dari perjanjian kerja tersebut, apakah perjanjian kerja tersebut PKWT atau PKWTT, karena berdasarkan Pasal 42 Ayat (4) Undang-Undang Nomor 13 Tahun 2003 tentang Ketenagakerjaan, TKA hanya dapat dipekerjakan untuk jabatan tertentu dan waktu tertentu, tetapi perjanjian kerja yang dibuat dan ditandatangani oleh Lau Chak Loong tidak mengatur mengenai jangka waktu.

Syarat sahnya perjanjian kerja mengacu pada syarat sahnya perjanjian perdata pada umumnya seperti yang ditentukan dalam Pasal 1320 Kitab Undang-Undang Hukum Perdata. ${ }^{20)}$ Berdasarkan Pasal 52 Undang-Undang Nomor 13 Tahun 2003 tentang Ketenagakerjaan, perjanjian kerja dibuat atas dasar:

\footnotetext{
${ }^{20)}$ Adrian Sutedi, Op. Cit., hal.45.
} 
1. Kesepakatan kedua belah pihak;

2. Kemampuan atau kecakapan melakukan perbuatan hukum;

3. Adanya pekerjaan yang diperjanjikan; dan

4. Pekerjaan yang diperjanjikan tidak bertentangan dengan ketertiban

Syarat nomor 1 (satu) dan syarat nomor 2 (dua), yaitu kesepakatan para pihak

dan kecakapan untuk membuat suatu perjanjian adalah syarat subyektif sahnya perjanjian yang menyangkut subyek (pihak) yang mengadakan perjanjian, yang apabila tidak dipenuhinya syarat subyektif mengakibatkan suatu perjanjian dapat dibatalkan. ${ }^{21)}$ Perjanjian kerja antara Lau Chak Loong dan PT Wira Pamungkas Pariwara di buat atas dasar kesepakatan dan pihak yang mengadakan telah cakap hukum yang mana telah memenuhi syarat subyektif sahnya perjanjian.

Syarat nomor 3 (tiga) dan syarat nomor 4 (empat), yaitu suatu hal tertentu dan suatu sebab yang halal adalah syarat obyektif sahnya perjanjian yang berhubungan langsung dengan obyek perjanjian, yang apabila tidak dipenuhinya syarat obyektif mengakibatkan suatu perjanjian batal demi hukum. $^{22)}$ Undang-undang memberikan kebebasan kepada para pihak untuk membuat dan mengadakan perjanjian yang melahirkan kewajiban apa saja selama dan sepanjang prestasi yang wajib dilakukan tersebut bukanlah sesuatu yang terlarang. Kitab Undang-Undang Hukum Perdata menyatakan bahwa suatu sebab yang terlarang adalah apabila dilarang oleh undang-undang, atau apabila berlawanan dengan kesusilaan atau ketertiban umum. ${ }^{23)}$ Keabsahan perjanjian ditentukan oleh terpenuhi atau tidaknya syarat-syarat yang ditentukan oleh undang-undang. Suatu perjanjian yang dibuat tidak memenuhi salah satu atau lebih prasyaratan yang ditentukan dalam Pasal 1320 Kitab Undang-Undang Hukum Perdata dan Pasal 52 Undang-Undang Nomor 13

21) Agus Yudha Hernoko, Hukum Perjanjian Asas Proporsionalitas dalam Kontrak Komersial, Cetakan ke-4, (Jakarta: Prenadamedia, 2014), 293.

22) Ibid., 293.

23) Agus Yudha Hernoko, Op. Cit., 162. 
Tahun 2003 tentang Ketenagakerjaan, maka perjanjian tersebut menjadi tidak sah, yang berarti perjanjian itu terancam batal. Hal ini mengakibatkan kebatalan menjadi perlu untuk diketahui oleh tiap pihak yang mengadakan perjanjian. ${ }^{24)}$ Pada kasus Putusan Pengadilan Hubungan Industrial Nomor: 274/Pdt.Sus-PHI/2015.PN.JKT.PST Jo Putusan Mahkamah Agung Nomor: 697 K/Pdt.Sus-PHI/2016, PT Wira Pamungkas Pariwara telah tidak memenuhi salah satu persyaratan sahnya perjanjian yang diatur dalam Pasal 1320 Kitab Undang-Undang Hukum Perdata dan Pasal 52 Undang-Undang Nomor 13 Tahun 2003 tentang Ketenagakerjaan, yaitu ketentuan syarat obyektif sahnya suatu perjanjian, yaitu suatu sebab yang halal, yang mengakibatkan perjanjian kerja antara Lau Chak Loong dan PT Wira Pamungkas Pariwara menjadi tidak sah. Di mana perjanjian kerja yang dibuat antara PT Wira Pamungkas Pariwara dan Lau Chak Loong dibuat dan ditandatangani dalam bahasa Inggris tanpa adanya perjanjian kerja dalam bahasa Indonesia, yang seharusnya menurut ketentuan perundang-undangan, perjanjian kerja tersebut harus dinyatakan batal demi hukum. Namun oleh karena dalam kasus ini, perjanjian kerja telah dilaksanakan dan telah berakhir, maka ketentuan yang mengatur mengenai pelanggaran syarat obyektif sahnya perjanjian tidak dapat diterapkan dalam kasus ini.

Muncul permasalahan pada saat dilakukan PHK terhadap Lau Chak Loong. Akibat dari perjanjian kerja yang tidak sesuai dengan undang-undang, yaitu PKWT antara PT Wira Pamungkas Pariwara dengan Lau Chak Loong tidak memenuhi unsur-unsur dari suatu PKWT, maka Lau Chak Loong sebagai TKA menganggap bahwa hubungan kerja yang ia jalani dengan PT Wira Pamungkas Pariwara adalah atas dasar PKWTT karena dalam perjanjian kerja tidak mengatur mengenai jangka waktu ia bekerja sehingga Lau Chak

\footnotetext{
24) Ibid., 172.
} 
Loong berhak atas hak pesangon, dan uang penggantian masa kerja saat PHK dilakukan.

Pada pertimbangan Majelis Hakim, baik pada Putusan Pengadilan Hubungan Industrial maupun pada Putusan Mahkamah Agung, Majelis Hakim menjelaskan bahwa walaupun perjanjian kerja antara Lau Chak Loong dengan PT Wira Pamungkas Pariwara melanggar ketentuan Pasal 57 Ayat (1) dan Pasal 59 Ayat (2) Undang-Undang Nomor 13 Tahun 2003 tentang Ketenagakerjaan, tidak dapat berubah menjadi PKWTT dikarenakan Lau Chak Loong adalah sebagai TKA. Perjanjian Kerja Waktu Tertentu yang tidak dibuat sesuai dengan Undang-Undang Nomor 13 Tahun 2003 tentang Ketenagakerjaan mengakibatkan dianggapnya PKWT tersebut menjadi PKWTT dengan segala akibat hukumnya, akan tetapi khusus bagi PKWT bagi TKA berlaku lex specialis yang berbeda dengan PKWT bagi tenaga kerja dalam negeri sehingga PKWT tidak secara serta merta dianggap sebagai PKWTT. Lex specialis tersebut dikarenakan secara historis dan tujuan pembentukan pasal-pasal mengenai TKA dalam Undang-Undang Nomor 13 Tahun 2003 tentang Ketenagakerjaan yang berbeda dengan tenaga kerja dalam negeri.

B. Perlindungan Hukum Terhadap Tenaga Kerja Asing Yang Tidak Memiliki Perjanjian Kerja Waktu Tertentu Yang Sesuai Dengan Undang-Undang Nomor 13 Tahun 2003 Tentang Ketenagakerjaan

Lau Chak Loong bekerja pada PT Wira Pamungkas Pariwara dengan perjanjian kerja yang tidak memenuhi unsur-unsur suatu PKWT. Perjanjian Kerja Waktu Tertentu merupakan bentuk perjanjian yang harus diadakan apabila seorang TKA bekerja di Indonesia, oleh karena TKA hanya dapat dipekerjakan di Indonesia untuk jangka waktu yang telah ditentukan. Perjanjian Kerja Waktu Tertentu dapat dibuat untuk jangka waktu paling lama 2 (dua) tahun dan dapat diperpanjang 1 (satu) kali untuk jangka waktu 1 (satu) 
tahun serta dapat dilakukan pembaharuan 1 (satu) kali untuk jangka waktu 2 (dua) tahun. Undang-Undang Nomor 13 Tahun 2003 tentang Ketenagakerjaan mengatur bahwa PKWT harus dibuat secara tertulis dengan menggunakan bahasa Indonesia dan huruf latin. Perjanjian Kerja Waktu Tertentu yang tidak dibuat secara tertulis dengan menggunakan bahasa Indonesia demi hukum berubah menjadi PKWTT. Namun dalam Undang-Undang Nomor 13 Tahun 2003 tentang Ketenagakerjaan juga mengatur bahwa TKA hanya dapat dipekerjakan untuk waktu tertentu. Sehingga penulis berpendapat bahwa pelanggaran dalam PKWT bagi TKA menimbulkan ketidakjelasan status TKA dalam memperoleh hak-haknya sebagai PKWT atau PKWTT yang dapat merugikan TKA.

Undang-Undang Nomor 13 Tahun 2003 tentang Ketenagakerjaan sebenarnya melindungi pekerja yang bekerja dengan PKWT, yaitu Pasal 62 Undang-Undang Nomor 13 Tahun 2003 tentang Ketenagakerjaan yang mengatur apabila salah satu pihak mengakhiri hubungan kerja sebelum berakhirnya jangka waktu yang ditetapkan dalam PKWT, atau berakhirnya hubungan kerja bukan karena ketentuan sebagaimana dimaksud dalam Pasal 61 Ayat (1) Undang-Undang Nomor 13 Tahun 2003 tentang Ketenagakerjaan, pihak yang mengakhiri hubungan kerja diwajibkan membayar ganti rugi kepada pihak lainnya sebesar upah pekerja/buruh sampai batas waktu berakhirnya jangka waktu perjanjian kerja. Namun karena PT Wira Pamungkas Pariwara melakukan pelanggaran perjanjian kerja terhadap Lau Chak Loong, yang salah satunya adalah perjanjian kerja yang dibuat tidak mencantumkan atau tidak mengatur mengenai jangka waktu perjanjian kerja, sehingga menimbulkan ketidakjelasan terhadap status TKA dan merugikan TKA dalam memperoleh hak-haknya. Menurut Bapak Rizki Nasution, ${ }^{25)}$

${ }^{25)}$ Peneliti, Wawancara, dengan Kasi Pelatihan dan Penempatan Tenaga Kerja Dalam Negeri Kementerian Ketenagakerjaan Republik Indonesia, (Jakarta: Kementerian Ketenagakerjaan Republik Indonesia, 22 Maret 2018). 
karena dalam perjanjian kerja tidak mengatur mengenai jangka waktu, maka jangka waktu bekerja TKA mengikuti jangka waktu berlakunya IMTA. Izin Mempekerjakan Tenaga Kerja Asing menjadi dasar dari pengajuan KITAS. Jangka waktu berlaku KITAS adalah 1 (satu) tahun. Berdasarkan Putusan Pengadilan Hubungan Industrial Nomor: 274/Pdt.Sus-PHI/2015.PN.JKT.PST Jo Putusan Mahkamah Agung Nomor: 697 K/Pdt.Sus-PHI/2016, yang digunakan sebagai acuan jangka waktu Lau Chak Loong bekerja pada PT Pamungkas Pariwara adalah KITAS. Kartu Ijin Tinggal Terbatas Lau Chak Loong berakhir pada bulan Juli 2015 yang artinya hubungan kerja antara PT Wira Pamungkas Pariwara dengan Lau Chak Loong berakhir pada Juli 2015, namun hubungan kerja antara Lau Chak Loong dan PT Wira Pamungkas Pariwara berakhir pada bulan Juni 2015. Artinya perusahaan seharusnya memberikan ganti rugi 1 (satu) bulan kepada Lau Chak Loong karena masih ada tersisa jangka waktu 1 (satu) bulan sebelum KITAS berakhir, sesuai dengan apa yang diatur oleh Pasal 62 Undang-Undang Nomor 13 Tahun 2003 tentang Ketenagakerjaan yaitu apabila salah satu pihak mengakhiri hubungan kerja sebelum berakhirnya jangka waktu yang ditetapkan dalam PKWT, pihak yang mengakhiri hubungan kerja diwajibkan membayar ganti rugi kepada pihak lainnya sebesar upah pekerja/buruh sampai batas waktu berakhirnya jangka waktu perjanjian kerja.

Pasal 42 Ayat (1) Undang-Undang Nomor 13 Tahun 2003 tentang Ketenagakerjaan menyatakan setiap pemberi kerja yang mempekerjakan TKA wajib memiliki izin tertulis dari Menteri atau pejabat yang ditunjuk. Izin merupakan hal yang paling pokok dimiliki oleh pemberi kerja dalam menggunakan TKA. Pertama bahwa seorang pemberi kerja TKA yang ingin mempekerjakan seorang TKA di perusahaannya harus memiliki RPTKA. Rencana Penggunaan Tenaga Kerja Asing adalah rencana penggunaan TKA pada jabatan tertentu yang dibuat oleh pemberi kerja TKA untuk jangka waktu tertentu yang disahkan oleh Menteri atau pejabat yang ditunjuk. Rencana 
Penggunaan Tenaga Kerja Asing tersebut salah satunya memuat jangka waktu dan alasan penggunaan TKA. Rencana Penggunaan Tenaga Kerja Asing merupakan dasar untuk mendapatkan IMTA, maka pemberi kerja TKA wajib memiliki IMTA. Izin Mempekerjakan Tenaga Kerja Asing adalah izin tertulis yang diberikan oleh Menteri atau pejabat yang ditunjuk kepada pemberi kerja TKA. Jangka waktu berlaku IMTA adalah 1 (satu) tahun dan dapat diperpanjang sesuai dengan Keputusan Menteri tentang jabatan-jabatan yang dapat diduduki oleh TKA atau RPTKA. Izin Mempekerjakan Tenaga Kerja Asing menjadi dasar untuk pengajuan KITAS yang digunakan untuk TKA bekerja di Indonesia yang merupakan kewajiban yang dimiliki TKA sesuai dengan peraturan perundang-undangan di Indonesia.

Tenaga Kerja Asing memiliki hak yang sama dengan tenaga kerja Indonesia. Tenaga kerja asing juga mendapatkan perlindungan dan perlakuan yang sama adilnya di depan hukum Indonesia. Berdasarkan hasil wawancara dengan Bapak Sehat Damanik, ${ }^{26)}$ salah satu bentuk nyata adanya perlindungan hukum terhadap TKA dalam kasus ini adalah TKA memiliki hak yang sama untuk mengajukan sengketa ke Pengadilan Hubungan Industrial dan Mahkamah Agung. Hal itu merupakan bentuk nyata dari perlindungan hukum yang diberikan pemerintah kepada TKA yang bekerja di Indonesia karena TKA dapat meminta bantuan kepada pemerintah Indonesia, dalam hal ini Pengadilan Hubungan Industrial dan Mahkamah Agung dalam menyelesaikan sengketa yang dihadapi, terlepas dari bagaimana hasilnya, apakah memenangkan pihak TKA atau pihak pemberi kerja TKA.

\section{Penutup}

\section{A. Kesimpulan}

Berdasarkan paparan analisis di atas, maka dapat disimpulkan sebagai berikut:

${ }^{26)}$ Peneliti, Wawancara, dengan Dosen Fakultas Hukum Universitas Tarumanagara, (Jakarta: Law Office of DSS and Partners, 18 April 2018). 
1. PT Wira Pamungkas Pariwara melanggar syarat-syarat PKWT terhadap Lau Chak Loong, antara lain; Pertama, PKWT yang dibuat melanggar Pasal 57 Undang-Undang Nomor 13 Tahun 2003 tentang Ketenagakerjaan, yaitu dibuat dalam bahasa Inggris tanpa adanya terjemahan dalam bahasa Indonesia. Kedua, PKWT antara PT Wira Pamungkas Pariwara dan Lau Chak Loong tidak mengatur mengenai jangka waktu berlaku. Sesuai dengan Pasal 56 Ayat (2) Undang-Undang Nomor 13 Tahun 2003 tentang Ketenagakerjaan, PKWT tentunya harus didasarkan atas jangka waktu tertentu yang termuat dalam perjanjian kerja, apabila dalam perjanjian kerja tidak memuat jangka waktu berlakunya tentu menimbulkan ketidakjelasan status bagi TKA. Ketiga, PKWT antara PT Wira Pamungkas Pariwara dan Lau Chak Loong tidak sesuai dengan undang-undang karena PKWT yang dibuat tidak mengatur mengenai jangka waktu, maka menimbulkan ketidakjelasan status Lau Chak Loong sebagai pekerja PKWT atau PKWTT. Karena perjanjian kerja yang dibuat tidak mencantumkan jangka waktu berlakunya, maka jangka waktunya mengacu pada jangka waktu berlaku IMTA. Namun berdasarkan Putusan Pengadilan Hubungan Industrial Nomor: 274/Pdt.Sus-PHI/2015.PN.JKT.PST Jo Putusan Mahkamah Agung Nomor: 697 K/Pdt.Sus-PHI/2016, yang digunakan sebagai acuan jangka waktu Lau Chak Loong bekerja pada PT Pamungkas Pariwara adalah KITAS. KITAS mengacu pada IMTA karena IMTA sebagai dasar untuk pengajuan KITAS. KITAS Lau chak Loong berakhir pada bulan Juli 2015, tetapi hubungan kerja Lau Chak Loong berakhir pada bulan Juni 2015, maka seharusnya perusahaan memberikan ganti rugi 1 (satu) bulan terhadap Lau Chak Loong. ${ }^{27)}$

27) Peneliti, Wawancara, dengan Kasi Pelatihan dan Penempatan Tenaga Kerja Dalam Negeri Kementerian Ketenagakerjaan Republik Indonesia, (Jakarta: Kementerian Ketenagakerjaan Republik Indonesia, 22 Maret 2018). 
Perjanjian Kerja Waktu Tertentu yang tidak dibuat sesuai dengan Undang-Undang Nomor 13 Tahun 2003 tentang Ketenagakerjaan mengakibatkan dianggapnya PKWT tersebut menjadi PKWTT dengan segala akibat hukumnya, akan tetapi khusus bagi PKWT bagi TKA berlaku lex specialis yang berbeda dengan PKWT bagi tenaga kerja dalam negeri sehingga PKWT tidak secara serta merta dianggap sebagai PKWTT. Lex specialis tersebut dikarenakan secara historis dan tujuan pembentukan pasal-pasal mengenai TKA dalam Undang-Undang Nomor 13 Tahun 2003 tentang Ketenagakerjaan yang berbeda dengan tenaga kerja dalam negeri.

2. Perlindungan hukum yang diberikan Pemerintah kepada TKA, salah satunya adalah pemberi kerja yang mempekerjakan TKA wajib memiliki izin tertulis dari Menteri atau pejabat yang ditunjuk. Izin merupakan hal yang paling pokok dimiliki oleh pemberi kerja dalam menggunakan TKA. Izin tertulis yang wajib dimiliki oleh pemberi kerja TKA adalah RPTKA dan IMTA. Selain itu, Pasal 62 Undang-Undang Nomor 13 Tahun 2003 tentang Ketenagakerjaan juga memberikan perlindungan kepada pekerja PKWT apabila salah satu pihak mengakhiri hubungan kerja sebelum jangka waktu berakhir maka pihak yang mengakhiri perjanjian kerja wajib memberikan ganti rugi sampai batas waktu berakhirnya jangka waktu perjanjian kerja. Bentuk perlindungan hukum lainnya adalah TKA memiliki hak yang sama seperti tenaga kerja dalam negeri untuk mengajukan sengketa ke Pengadilan, dalam hal ini Pengadilan Hubungan Industrial dan Mahkamah Agung dalam menyelesaikan sengketa yang dihadapi, terlepas dari bagaimana hasilnya, apakah memenangkan pihak TKA atau pihak pemberi kerja TKA.

\section{B. Saran}


Saran yang dapat Penulis berikan adalah seharusnya Pemerintah lebih memperketat pengawasan terhadap TKA, karena pada kenyataannya masih banyak TKA yang bekerja di Indonesia tanpa izin resmi atau ilegal. Selain itu pula, banyak terjadi di mana perusahaan melakukan pelanggaran-pelanggaran perjanjian kerja terhadap TKA. Hal tersebut tentu dapat merugikan TKA yang bekerja di Indonesia. Munculnya Peraturan Presiden Nomor 20 Tahun 2018 tentang Penggunaan Tenaga Kerja Asing, mewajibkan pemberi kerja TKA memiliki RPTKA sebagai izin mempekerjakan TKA dan menghapuskan IMTA sebagai izin mempekerjakan TKA, hal ini dilakukan Pemerintah untuk mempermudah TKA bekerja di Indonesia dalam memenuhi kebutuhan tenaga kerja terampil dan professional dibidang tertentu yang belum dapat diisi oleh pekerja lokal sehingga bisa terjadi proses transfer of expertise atau transfer keahlian, teknologi dan pengetahuan dari TKA kepada pekerja lokal sehingga dapat membentu mempercepat proses pembangunan nasional dan mendorong investasi asing untuk pembangunan dan pertumbuhan ekonomi.

\section{Daftar Pustaka}

\section{A. Buku:}

Budiono, Abdul Rachmad. Hukum Perburuhan di Indonesia. Cetakan ke-3. (Jakarta: Raja Grafindo Persada, 1999).

Djumadi. Hukum Perburuhan Perjanjian Kerja. Cetakan ke-5. (Jakarta: Raja Grafindo Persada, 2008).

Djumialdji, F.X. Perjanjian Kerja Edisi Revisi. Cetakan ke-3. (Jakarta: Sinar Grafika, 2008).

Hernoko, Agus Yudha. Hukum Perjanjian Asas Proporsionalitas dalam Kontrak Komersial. Cetakan ke-4, (Jakarta: Prenadamedia, 2014). 
Sutedi, Adrian. Hukum Perburuhan. Cetakan ke-1. (Jakarta: Sinar Grafika, 2009).

Uwiyono, Aloysius et al. Asas-asas Hukum Perburuhan. Cetakan ke-2. (Jakarta: Raja Grafindo Persada, 2014).

Wijayanti, Asri. Hukum Ketenagakerjaan Pasca Reformasi. Cetakan ke-1, (Jakarta: Sinar Grafika, 2009).

\section{B. Peraturan Perundang-undangan:}

Indonesia. Kitab Undang-Undang Hukum Perdata.

. Undang-Undang Nomor 13 Tahun 2003 Tentang Ketenagakerjaan (Tambahan Lembaran Negara Republik Indonesia Nomor 4279).

- Peraturan Presiden Republik Indonesia Nomor 20 Tahun 2018 Tentang Penggunaan Tenaga Kerja Asing.

. Peraturan Menteri Ketenagakerjaan Republik Indonesia Nomor 16 Tahun 2015 Tentang Tata Cara Penggunaan Tenaga Kerja Asing.

. Peraturan Menteri Ketenagakerjaan RI Nomor 35 Tahun 2015 tentang Perubahan Atas Peraturan Menteri Ketenagakerjaan Nomor 16 Tahun 2015 Tentang Tata Cara Penggunaan Tenaga Kerja Asing.

. Keputusan Menteri Tenaga Kerja dan Transmigrasi Nomor KEP 100/MEN/VI/2004 Tentang Ketentuan Pelaksanaan Perjanjian Kerja Waktu Tertentu

Keputusan Menteri Tenaga Kerja dan Transmigrasi Nomor 40 Tahun 2012 Tentang Jabatan-Jabatan Tertentu Yang Dilarang Diduduki Tenaga Kerja Asing.

\section{Putusan}


Indonesia. Putusan Pengadilan Hubungan Industrial Nomor: 274/Pdt.SusPHI/2015.PN.JKT.PST.

Putusan Mahkamah Agung Nomor: 697 K/Pdt.Sus-PHI/2016.

\section{Internet}

Humas. "Inilah Perpres Nomor 20 Tahun 2018 tentang Penggunaan Tenaga kerja Asing". http://setkab.go.id/inilah-perpres-nomor-20-tahun-2018tentang-penggunaan-tenaga-kerja-asing. Diakses tanggal 29 Mei 2018.

Safri Haliding. "Pengawasan Tenaga Kerja Asing". http://thinktank.matagaruda.org/read/74/pengawasan-tenaga-kerjaasing. Diakses tanggal 5 Juni 2018.

Woro Seto. "Perpres Nomor 20 Tahun 2018, Fadli Zon: Isu TKA Bukan Sengaja Digoreng atau Dibesar-besarkan". http://wow.tribunnews.com/2018/05/02/perpres-nomor-20-tahun-2018fadli-zon-isu-tka-bukan-sengaja-digoreng-atau-dibesar-besarkan.

Diakses tanggal 29

Mei

2018. 